\title{
Sources and frequency of brood loss in solitary bees
}

\author{
Robert L. MinCKLEY ${ }^{1}$, Bryan N. DANFORTH ${ }^{2}$ \\ ${ }^{1}$ Department of Biology, University of Rochester, Rochester, NY 14620, USA \\ ${ }^{2}$ Department of Entomology, Cornell University, Ithaca, NY 14853, USA
}

Received 4 February 2019 - Revised 17 April 2019 - Accepted 4 June 2019

\begin{abstract}
We surveyed the literature for reports of parasites, predators, and other associates of the brood found in the nests of solitary bees. Studies were included in this survey if they reported the contents of all the bee brood cells that they examined. The natural enemies of solitary bees represented in the studies included here were taxonomically diverse. Although a few studies report high loss of solitary bee brood to a species-rich set of natural enemies, most studies report losses of less than $20 \%$ to few natural enemies. Brood parasitic bees are the greatest source of mortality for immatures of pollen-collecting solitary bees followed by meloid beetles (Meloidae), beeflies (Bombyliidae), and clerid beetles (Cleridae). Most groups, however, are reported from only a few host species and attack a low proportion of brood cells. Mortality due to unknown causes is also common. The suite of natural enemies that attack ground- and cavity-nesting solitary bees is very different. The cavity-nesting species have higher reported mortality due to unknown causes perhaps related to how nests are manipulated and handled by researchers.
\end{abstract}

\section{brood parasite / predator / cavity-nesting bees / ground-nesting bees / meta-analysis}

\section{INTRODUCTION}

The adults and immature stages of solitary bees are attacked by other bee species, insects other than bees, vertebrates, fungi, and microbes. Also living in solitary bee nests are an insect fauna that consumes material left behind after larval bees mature and leave the nest. These scavengers sometime kill host brood incidentally. Most enemies of solitary bees gain access to the nest as adults that oviposit into open cells or as specialized, highly mobile triungulin larvae that attack the host at early larval stages. The fascinating biology of many of these groups

Electronic supplementary material The online version of this article (https://doi.org/10.1007/s13592-019-00663-2) contains supplementary material, which is available to authorized users.

Corresponding author: R. Minckley, robert.minckley@rochester.edu

Handling editor: James Nieh (reviewed in Clausen 1940; Danforth et al. 2019; Linsley 1958) is known from studies that either have excavated solitary bee nests from the soil or have opened nests in twigs and stems. The number of associates within the nests of solitary bees can be high. Linsley and MacSwain (1942) found 22 insect species associated with several dense nesting aggregations of Anthophora linsleyi and the 15 species that attacked brood of the host bee inflicted more than $50 \%$ mortality. In contrast, a large 30year-old nesting aggregation of Dieunomia triangulifera hosted just five species of natural enemies (Wcislo et al. 1994; Wuellner 1999). Total mortality at the $D$. triangulifera nest site varied from 11 to $29 \%$, depending on the year (Wcislo et al. 1994). Nest density and how long sites are reused for nesting are two of a number of factors that may influence brood loss of solitary bees (Rosenheim 1990). Other factors that influence brood loss include phenological synchrony (Wcislo 1987), parasite density (Rehan et al. 2011; Goodell 2003), resource availability 
(Goodell 2003), pollen chemistry (Spear et al. 2016), nest architecture (Stephen et al. 1969), habitat size (Howell et al. 2017), and nest location (Wcislo 1996). There is a growing list of experimental studies of hosts and parasites involving solitary bees that are difficult to generalize beyond the species involved in the study. Wcislo (1996) compared solitary bees and wasps nesting either above- or belowground-nesting species and found no significant difference in brood loss among the two groups. At present, there is no set of ecological conditions or life history traits that strongly predict levels of brood loss across solitary bees as a whole.

The primary aim of this paper is to make available the information on the parasites and others nest associates of solitary bees reported in the literature that we gathered as part of a larger project (Danforth et al. 2019). This compilation differs from Wcislo (1996) in that only Apiformes are included (apoid wasps were not recorded) and studies done since 1996 are included. We recorded information from any study that reported the number of bee cells examined and all of their contents. All studies that report contents determined them by direct examination of the nest, except for one study that used emergence traps (Minckley et al. 1994). This survey reveals many gaps in our knowledge. For example, overrepresented are some groups of bees such as trap-nesting Megachilidae and species from North America. It nevertheless provides a baseline that can be used to guide future research. Wcislo (1996) detailed problems interpreting these kinds of datasets and how and why they violate a number of basic tenets of statistics, particularly non-independence due to phylogenetic relatedness. With these caveats (and others), we report estimates of brood loss of solitary bees due to predation and/or parasitism and due to unknown causes that occur during development from egg to adult. We also gauge how the suite of natural enemies differ among ground-nesting and cavity-nesting solitary bees and examine if the different modes of attack used by these enemies predict which groups are more successful than others. Finally, we examine if there is evidence that natural enemy attack is greater for bees that persistently nest at the same site for multiple generations than for bees that have occupied a site for the first time.

\section{METHODS}

We compiled information on in-nest mortality due to natural enemies and other nest associates of solitary bees from any peer-reviewed study that reported both the number of solitary bee cells examined and their contents. The contents of each cell were often individuals of the host species, but reports of empty cells, cells inhabited by other insects, mites or fungi were taken to indicate evidence of host larval mortality. We included a study if they identified insects to the taxonomic level of family or below. An exception to this rule was necessary for mites and fungi, as their identification was often more general than that of family. Although some identifications are above the family level and others are below, e.g., the genus Melittobia (Eulophidae), hereafter we use family to refer to groups of natural enemies of any taxonomic rank. It is not unusual for more than one species in a family to be reported in a study, so the categorization reported here does not necessarily mirror the actual species richness of pathogens, parasites, and predators.

\subsection{Host bee attributes}

For each host bee species, we recorded if the authors indicated that the nest site was newly established (annual) or had been occupied for multiple years (persistent). The mention of old cells interspersed with provisioned cells could indicate that the nest site had been used the previous year or at least that there had been a generation from earlier in the same year that the study occurred. The nest site was scored as persistent in the latter case. We also recorded if the species nested in the ground or above ground in cavities of twigs, stems, or trap nests. Trap nests can result in artificially dense aggregations of nests that may influence the success of predators and parasites (Wcislo 1984; Rosenheim 1990). We therefore categorized species that nest above ground into two groups, those that inhabited trap nests and those found in naturally occurring cavities. 


\subsection{Natural enemy attributes}

Identification of the nest associates of solitary bees allowed us to infer a cause of death for the host. Sources of mortality include those that prey on the egg and feed on the provision mass (brood parasitic bees, some Meloidae), predators of late instar larvae or pupae (Bombyliidae, Ripiphoridae, Chaetodactylidae, etc.), food depredators that consume the provision mass (Meloidae; Drosophilidae, Cacoxenus), and scavengers of debris left behind from host larvae that incidentally have an adverse impact on the host bee. When a brood cell contained a dead immature of the host, we scored it as a death due to an unknown cause recognizing that mortality could be by a pathogen (fungal, protozoan, bacterial, or viral) or a problem related to proper development. The presence of mold in the cells was often difficult to categorize, as these cases may represent saprophytes that infested the bee after it died of other (unknown) causes or, alternately, were the primary agent of mortality (for example, Ascosphaera). If the mold was not identified as Ascosphaera, a group known to attack living insects, we scored the cause of death as unknown and considered the mold to be a saprobe. This convention may slightly inflate our estimates of brood mortality by unknown causes. A similar problem is related to cells with mites inside. Mites may be the primary cause of mortality for developing bees or they may be beneficial mutualists that consume fungi and bacteria within the cell (Biani et al. 2009). We included reports of mites in the ectoparasite category any time they were not identified to a level where they could be confidently considered an ectoparasite or symbiont.

We further categorized the insects that attack solitary bee brood cells into how they gained access to the nest. Adults of most species either enter the nest through the entrance and locate a larval host cell or oviposit through the sides and lay eggs or early instar larvae. However, others rely on active first instar larvae, or triungulins, that enter the nest through the entrance or attach themselves to foraging bees at flowers or around the nest entrance as bees return to the nest.

\subsection{Mortality estimates}

Any study was included in the compilation of studies, although we limited calculations of the summary statistics to studies that reported the contents of 10 brood cells or more. When more than one study has been published on the same species (Ceratina calcarata, Hoplitis fulgida, and Megachile mendica: see supplemental Table 1), the study with the largest number of cells observed was used in the calculations. Nest contents of Osmia sanrafaelae were reported from trap nests and nests in cracks in soil banks. The majority of the nests were from trap nests so we included all their contents in the trap nest category.

We calculated the percent mortality for each of the mortality factors in three ways: (1) the number of studies, or reports, that observe a mortality agent out of the total number of studies; (2) the mean proportion of cells attacked across the studies; and (3) incidence of all reports. Incidence was calculated as follows: assume there are 60 studies and in those 60 studies, there are reports of a total of 300 natural enemy attacks (because more than one group attacks the brood of any one bee species). Then, if bee flies are responsible for 50 attacks the incidence (expressed as a percentage) would be $50 / 300 \times 100=16.7 \%$.

\section{RESULTS}

We found 111 published reports that detail the brood cell contents and natural enemies of 147 taxa of solitary bees (Suppl. Table 1). Data for 32 studies were not included in calculations of summary statistics because less than 10 cells were examined ( 9 species), species in the same genus were pooled (Megalopta and Xylocopa), the species was studied by more than one author (4 species), or for other reasons detailed in the footnotes of supplementary Table 1. A study of Osmia rufa reported larval mortality by the gall-forming fly, Giraudiella inclusa (Madras-Majewska et al. 2011) which we did not include because mortality was related to formation of the gall in the Phragmites canes used as artificial trap nests and therefore was incidental to the presence of the bees.

Of the 115 species that report the contents of 10 or more brood cells (supplemental Table 1), 61 


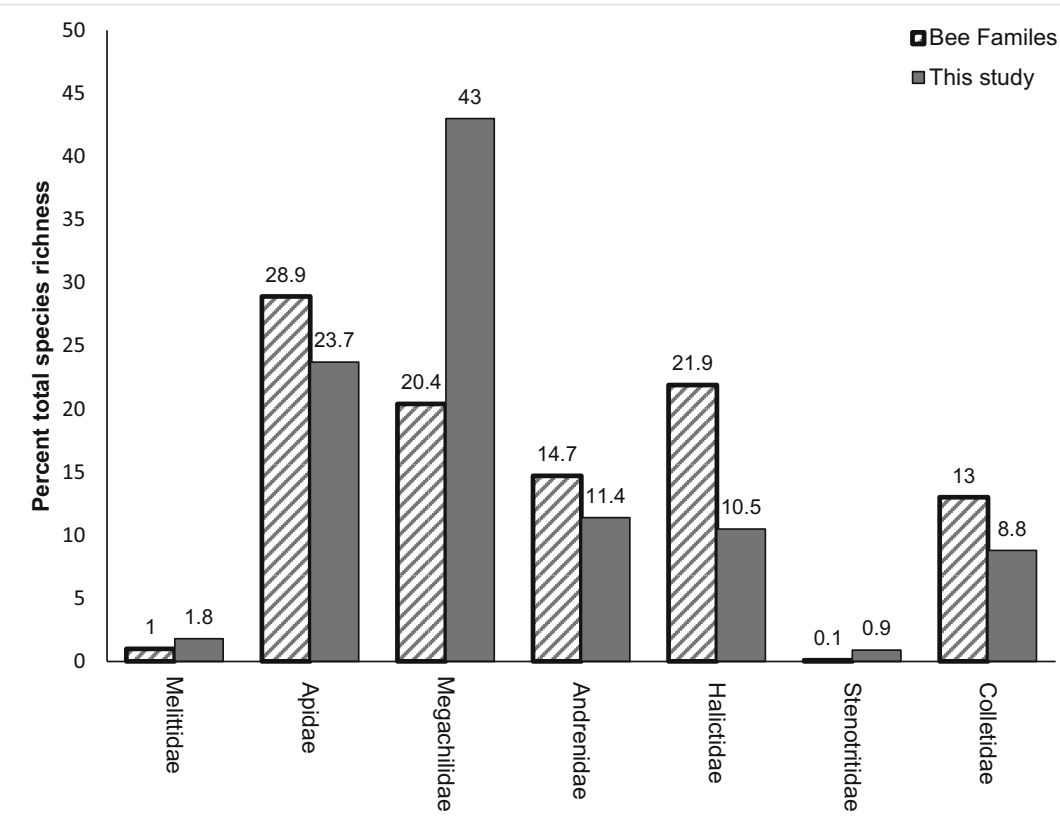

Figure 1 Percent species richness of each bee family compared to the percent species richness of each bee family included in this study. Species included here are only those that were used to calculate summary statistics (see text). In this survey, species of Megachilidae are overrepresented and species of Halictidae are underrepresented.

reported the contents of more than 100 cells. More species in the family Megachilidae have been studied than from any other family (Figure 1). In this survey, species richness of Megachilidae was overrepresented by a factor of two and Halictidae was underrepresented by a factor of one-half compared to their representation across bee families as a whole (Figure 1). The interest in social behavior of the Halictidae has resulted in nest descriptions of many species (Sakagami and Michener 1962), but only those that are solitary are included here. The 115 studies on solitary bees were divided equally among species that nested in the ground $(N=57)$ and those that nested above ground ( $N=$ $58)$. The majority of species that nested above ground were studied from artificially constructed trap nests $(N=45$ of 58), nests of Hylaeus brevicornis and Hoplitis leucomelana, were examined from both trap nests and from twigs, and Osmia sanrafaelae were from trap nests and nests in cracks in the soil.

Other than mites (Acari) and molds (Fungi), natural enemies were insects from five Orders; Hymenoptera (16 families), Diptera (4 families),
Coleoptera (3 families), Lepidoptera (1 family), and Neuroptera (1 family) (Tables I and II). Molds and fungi are commonly reported in solitary bee nests as are a suite of scavengers that sometimes incidentally damage or kill bee larvae as they consume pollen, feces, and other materials in the nest (Table II) (Linsley 1944). Some known predators and parasites of solitary bee larvae were not reported in the studies we used for summary statistics (i.e., birds, mammals, Strepsiptera) so are not listed in Table I as natural enemies or nest associates.

Cleptoparasitic bees are the largest source of mortality when all studies are pooled (Table I, supplementary Table 1) and for ground-nesting and cavity-nesting bees when these two categories are considered separately (Figure 4). About half of all studies report brood loss due to cleptoparasitic bees and these amount to a $22.5 \%$ incidence (Table I). The average proportion of cells lost to brood parasitic bees is $6.7 \%$ (Table I). The top five natural enemies that are not bees in terms of incidence are the Meloidae, Bombyliidae, Cleridae, Torymidae, and Sapygidae in descending order. The incidence of reports for 15 families 
Table I. Natural enemies of solitary bees reported from the cell contents of 111 solitary bee species. Natural enemies are grouped according to their primary food source, the host larva or the pollen and nectar provisions, and then ranked by incidence. Nest associates that consume the provision mass of the host larvae also often consume the larva. Indicated is how entry into the cell is achieved, the number of studies that the natural enemy was reported, and the incidence (in percent out of 226) of reports of all studies, and the mean proportion of host cells attacked. Eulophidae* includes all members of the family other than Melittobia . Table 11-2 in Danforth et al. (2019) is based on these same data but reported values calculated from nests that examined 100 cells or more in contrast to this study that included any nest that examined 10 cells or more

\begin{tabular}{|c|c|c|c|c|}
\hline Classification & Mode of nest entry & Num studies & \%Incidence & Mean prop. cells lost \\
\hline \multicolumn{5}{|l|}{ Host larva consumed } \\
\hline Diptera: Bombyliidae & Triungulin & 22 & 9.7 & 1.11 \\
\hline Coleoptera: Cleridae & Triungulin & 18 & 8.0 & 1.14 \\
\hline Hymenoptera: Torymidae & Adult & 12 & 5.3 & 0.42 \\
\hline Hymenoptera: Chrysididae & Adult & 10 & 4.4 & 0.30 \\
\hline Unknown predation & $?$ & 9 & 4.0 & 0.19 \\
\hline Hymenoptera: Melittobia & Adult & 7 & 3.1 & 0.36 \\
\hline Hymenoptera: Mutillidae & Adult & 8 & 3.1 & 0.35 \\
\hline Hymenoptera: Chalcididae & Adult & 7 & 3.1 & 0.25 \\
\hline Acari & Adult & 5 & 2.2 & 0.66 \\
\hline Hymenoptera: Leucospidae & Adult & 5 & 2.2 & 0.22 \\
\hline Hymenoptera: Formicidae & Adult & 4 & 1.8 & 0.05 \\
\hline Hymenoptera: Eurytomidae & Late larvae? & 5 & 1.8 & 0.06 \\
\hline Diptera: Phoridae & Adult & 4 & 1.8 & 0.26 \\
\hline Coleoptera: Ripiphoridae & Triungulin & 4 & 1.3 & 0.65 \\
\hline Hymenoptera: Encyrtidae & Adult & 2 & 0.9 & 0.01 \\
\hline Hymenoptera: Ichneumonidae & Adult & 2 & 0.9 & 0.04 \\
\hline Hymenoptera: Pteromalidae & Adult & 2 & 0.9 & 0.01 \\
\hline Hymenoptera: Eulophidae* & Adult & 2 & 0.9 & 0.29 \\
\hline Unknown parasite & $?$ & 2 & 0.9 & 0.35 \\
\hline Neuroptera: Mantispidae & Triungulin & 1 & 0.4 & 0.06 \\
\hline Hymenoptera: Eupelmidae & Adult & 1 & 0.4 & $<0.01$ \\
\hline Hymenoptera: Gasteruptiidae & Adult & 1 & 0.4 & 0.06 \\
\hline Fungi: Onygenales: Ascosphaera & & 1 & 0.4 & $<0.01$ \\
\hline \multicolumn{5}{|l|}{ Larval provisions consumed } \\
\hline Hymenoptera: Apiformes & Adult & 52 & 22.5 & 6.68 \\
\hline Coleoptera: Meloidae & Triungulin & 24 & 10.6 & 1.66 \\
\hline Hymenoptera: Sapygidae & Adult & 11 & 4.8 & 0.88 \\
\hline Diptera: Drosophilidae: Cacoxenus & Adult & 4 & 1.8 & 0.50 \\
\hline Diptera: Miltogramminae & Adult & 3 & 1.3 & 0.10 \\
\hline Lepidoptera: Pyralidae & Unknown & 3 & 1.3 & 0.04 \\
\hline
\end{tabular}

of natural enemies is less than $2 \%$. Only 4 of the 28 families (Apiformes, Meloidae, Bombyliidae, Cleridae) result in an average mortality of more than $1 \%$ when proportional loss is averaged across all studies (Table I).
Access to the host nest is by the adult female for all cleptoparasitic bees; however, other groups that attack solitary bee brood use an array of tactics. When we grouped non-bee parasites and predators by how they enter the larval host bee 
Table II. Organisms that attack adult bees or are consumers of dead larvae, unconsumed provisions, larval feces or other cell contents found in larval cells of solitary bees. Note that the Chloropidae are cleptoparasites or depredators that do not kill the host larva (Smith et al. 2018)

\begin{tabular}{lc}
\hline & Num. studies \\
\hline Adult consumed & \\
Diptera: Stylopidae & 0 \\
Diptera: Conopidae & 4 \\
Saprobes & \\
Mites or mold & 1 \\
Fungi: "mold" & 12 \\
Acari & 6 \\
Scavengers & \\
Coleoptera: Cucujidae & 1 \\
Lepidoptera: Tineidae & 1 \\
Coleoptera: Dermestidae & 4 \\
Coleoptera: Anobiidae (Ptinidae) & 3 \\
Diptera: Anthomyiidae & 2 \\
Diptera: Chloropidae & 1 \\
\hline
\end{tabular}

cells, the most common groups are those that rely on an active first instar larva (Bombyliidae, Meloidae, and Cleridae: Table I). Less often reported are natural enemies that rely on the adult to enter the nest and find a larval bee (Mutillidae, Melittobia ) and those that pierce through the cell wall with an ovipositor to gain access to larvae (Sapygidae, Chrysididae, Torymidae) (Table I).

Average mortality for all studies combined was $29.1 \% \pm 23.6$ s.d. (range $0-87 \%$ ). Thirty-one studies reported less than $10 \%$ brood mortality and 29 reported more than $45 \%$ brood mortality. Brood mortality attributable to attack by natural enemies was slightly higher (mean $=16.2 \%+17.3$ s.d. [range 0-65.3]) than unknown brood mortality $(12.2 \% \pm 16.3$ s.d., range $0-81 \%)$ (Figure 2a). Attackers from few families were found in most nests (Figure 3a: mean=2.0 +2.8 s.d. (range 0-8).

Mortality for the ground-nesting species averaged $21.5 \% \pm 22.2$ s.d (range $0-87.0$ ) with the lowest mortality category $(0-5 \%)$ the most frequent. Brood loss due to natural enemies was much higher $($ mean $=16.3 \% \pm 18.0$ s.d. $[$ range $0-58.8])$ than brood mortality that was not attributable to a parasite or a predator $(5.2 \% \pm 10.5$ s.d., range 0 $42.4 \%$ ) (Figure $2 b$ ). The number of families reported in the nest other than the host bee species averaged $1.4+1.4$ s.d. (range $0-8$ ) (Figure $3 b$ ).

Mortality for the cavity-nesting species was greater (mean $36.9 \% \pm 23.1$ s.d., range 0-86.2) than it was for ground-nesting species (Figure 2c). This difference was largely due to mortality by unexplained factors; average mortality for this category was much higher $($ mean $=20.0 \% \pm 18.1$ s.d. [range 0-81.0]: Figure 2c) than it was for groundnesting species whereas mortality due to attack was close to the same for both groups $($ mean = $16.6 \% \pm 16.8$ s.d. [range 0-65.6]: Figure 2c). The average number of families reported in the nest other than the host bee species was higher for cavity-nesting bees than for ground-nesting bees $(2.3 \pm 1.9$ s.d., range $0-7$ : Figure $3 \mathrm{c})$.

The suite of natural enemies differs among species of ground-nesting and cavity-nesting solitary bees (Figure 4). Cleptoparasitic bees are the major source of mortality for both groups; however, ground-nesting bees are attacked more heavily by Meloidae and Bombyliidae than cavity-nesting bees and some groups that represent $<5 \%$ brood loss to cavity-nesting bee species (Cleridae, Sapygidae, Torymidae, Chrysididae, Melittobia) are very rarely reported attacking ground-nesting bee species. Of the 115 studies from which we calculated summary statistics, ten families of Hymenoptera (Chalcididae, Encyrtidae, Eulophidae [including Melittobia ], Eupelmidae, Eurytomidae, Formicidae, Gasteruptiidae, Leucospidae, Pteromalidae) and one family of Diptera (Drosophilidae) were found in nests of cavitynesting bees and not from nests of ground-nesting bees. In contrast, only three families reported from ground-nesting bees were not represented in the list of natural enemies for cavity-nesting bees (Ripiphoridae, Miltogramminae, Mantispidae).

It was not always possible to determine if the nest site was newly established or had been used for more than one generation. We scored nest sites of 29 species as newly established and 47 species from nest sites that had been used for multiple generations and, most often, years. Larval mortality due to natural enemies was very similar (13.5 \pm 19.3 s.d. newly established; $13.0 \pm 15.6$ s.d. persistent $)$ 
a all species combined

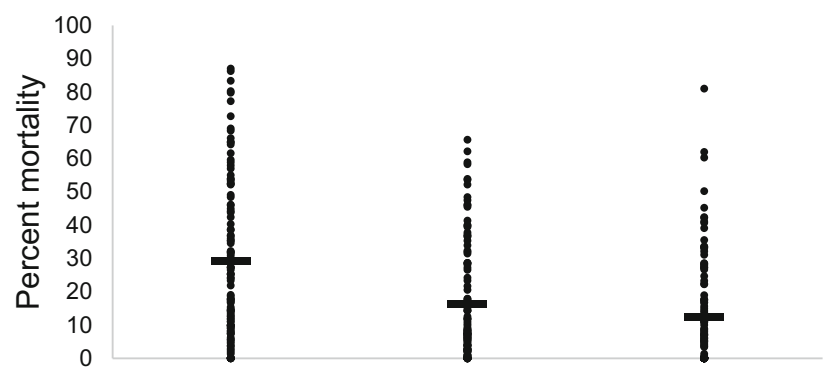

b ground-nesting species

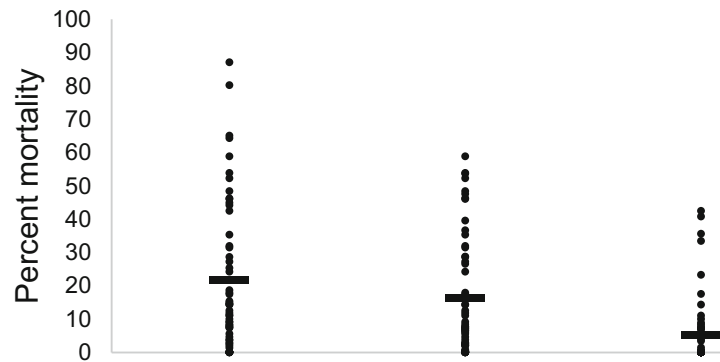

C cavity-nesting species

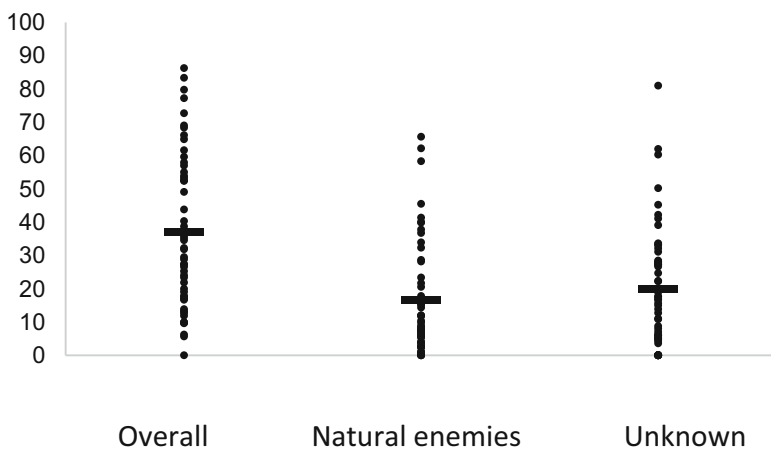

Figure 2 Percent brood mortality for a all species, $\mathbf{b}$ only ground-nesting species, and $\mathbf{c}$ only cavity-nesting species. Overall mortality is shown along with the contribution attributable to natural enemies and to unknown factors. The mean is indicated by the horizontal bar. In general, the values among groups of bees correspond closely except for the elevated mortality due to unknown causes for cavity-nesting bees.

\section{DISCUSSION}

The studies assembled in this survey identify cleptoparasitic bees as the most important natural enemy of solitary bees regardless of where they nest (below or above ground). For ground-nesting bees, the next most important natural enemies based on percent brood cell loss were Meloidae,
Bombyliidae, Ripiphoridae, and Acaridae (in descending importance). After cleptoparasitic bees, the major enemies of cavity-nesting bees were Cleridae, Sapygidae, Drosophilidae, and Torymidae.

Average brood loss is greater for cavity-nesting bees than for ground-nesting bee species. This difference appears to be related to the higher mortality of cavity-nesting bees due to unknown factors. 
a all species combined
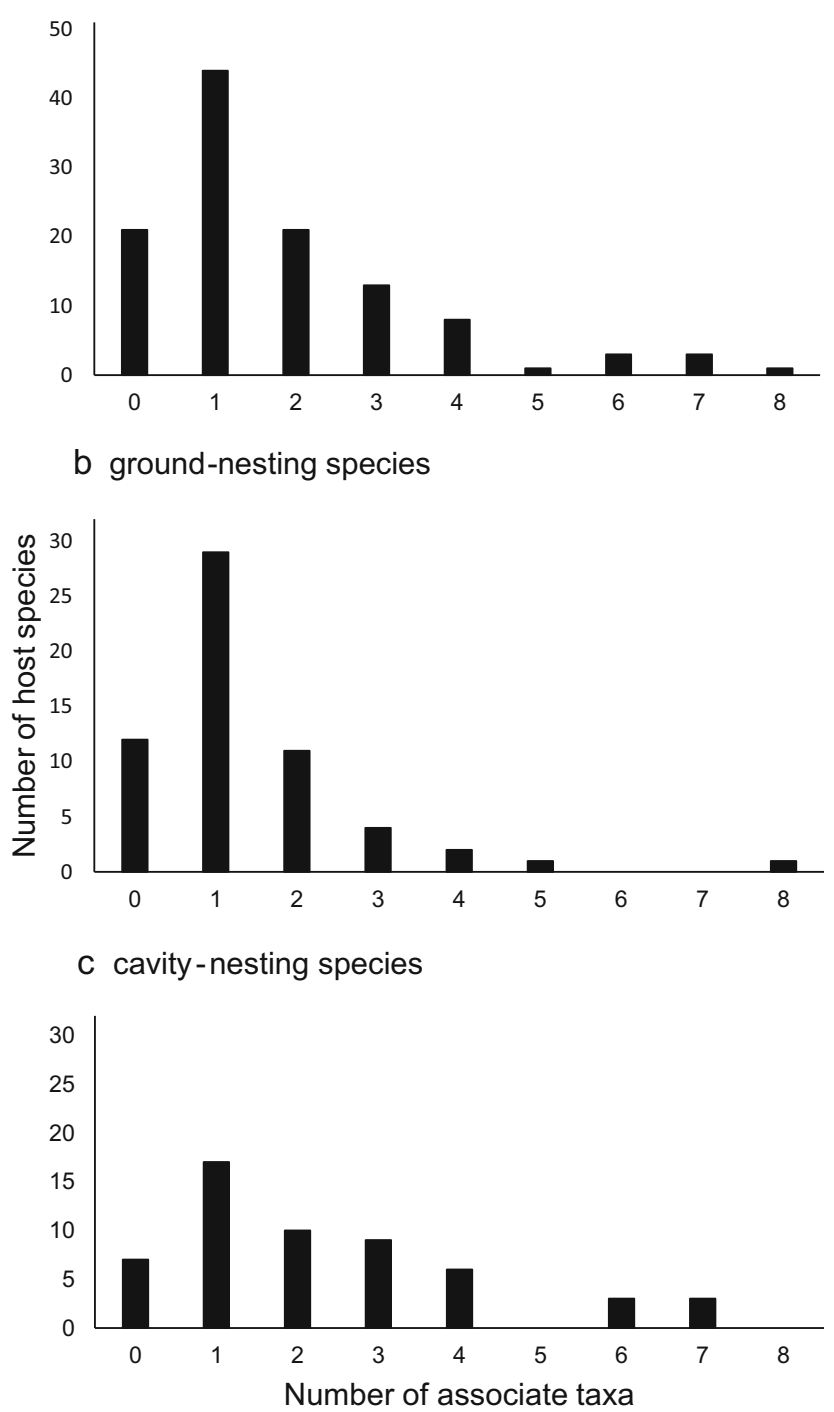

Figure 3 Number of families of nest associates reported for a all solitary bee species combined, $\mathbf{b}$ ground-nesting species, and c cavity-nesting species.

Brood loss due to natural enemies is close to the same for cavity-nesting and ground-nesting bees. Wcislo (1994) found no difference in mean mortality among cavity-nesting and ground-nesting bees but did not include mortality due to unknown factors, so his results broadly agree with our findings. One possible explanation for the high mortality of cavity-nesting bees, and one we have not seen mentioned in the literature, is that nests of cavity-nesting species are more often returned to the laboratory.
Elevated mortality may be related to jostling during transit or to less than ideal environmental conditions in the laboratory. Parker (1986) found that eggs and young larvae of Osmia sanrafaelae suffered higher mortality in trap nests with smaller diameter holes and speculated that differences in temperature or humidity were the cause. Future studies interested in estimating sources of mortality of cavity-nesting bees should consider these factors if estimates are of population parameters. 


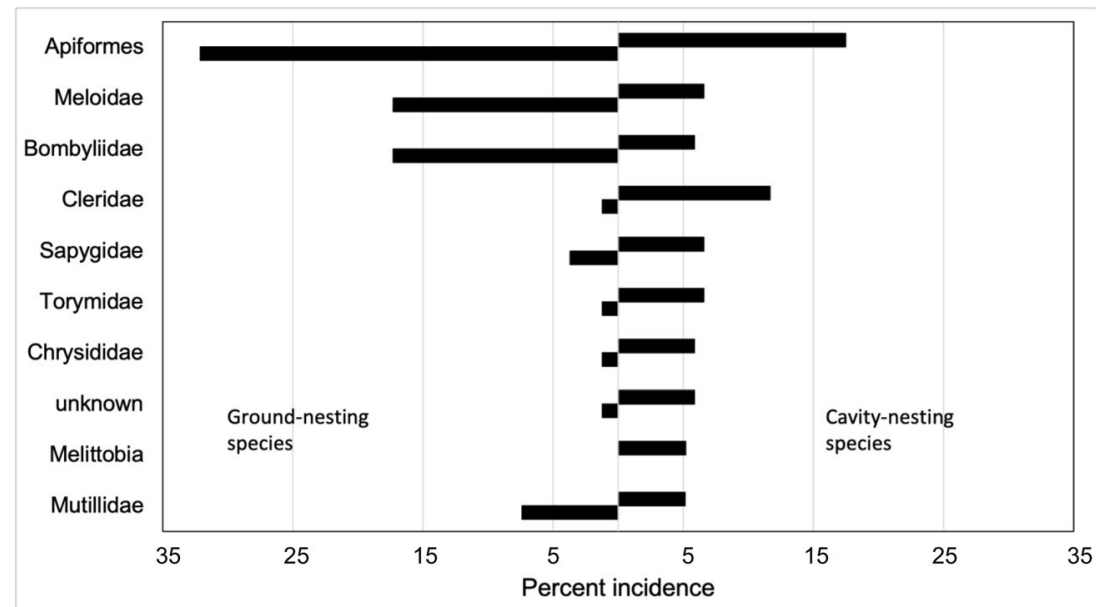

Figure 4 Percent mortality of brood loss due to the ten most important natural enemies of ground-nesting and cavitynesting solitary bee species. Ranking is based on percent loss of brood cells of all species pooled together. Many families of natural enemies reported from nests of cavity-nesting bees are rare or absent from nests of ground-nesting bees.

Grissell (2007) reviewed host records of the parasitoid wasp group Chalcidoidea and found there were more records of attack on cavitynesting species than on ground-nesting species, but cautioned that this difference may be due to reporting bias rather than biological reality. Our survey includes Hymenoptera outside the Chalcidoidea (Ichneumonidae, Sapygidae) and publications on Chalcidoidea done since Grissell's 2007 review. Nevertheless, our data also indicate that groups that use their ovipositor to attack brood (which are predominately Chalcidoidea) are most often reported from studies of cavity-nesting bees.

Although a few studies report very high mortality of brood and the presence of many nest associates, most studies report less than 20\% brood loss (Wcislo 1996; Smith et al. 2018) and very few natural enemies in the nest (Figures 2 and 3). This is the case both for bees that nest in the ground and those that nest in cavities. A few studies that examined many cells are notable for the complete lack of nest associates. No nest associates were found after numerous cells were examined of Epicharis zonata (Roubik and Michener 1980). This nesting aggregation was submerged underwater each wet season which may contribute to their total escape from natural enemies. However, Rust (1980) examined 125 cells of Ptilothrix bombiformis and also found no natural enemies, and Rozen and Buchmann (1990) found only one cell attacked of the 325 they examined from an enormous nest aggregation in the Sonoran Desert of Centris caesalpiniae. Trap nests aggregate bee species artificially and more so than normal (Krombein 1967; MacIvor and Packer 2015), and we find that their average loss to natural enemies differs only slightly from that of ground-nesting bees (Figure 2b, c). These examples and others listed in supplementary Table 1 show that aggregated nests do not invariably result in unusually high accumulations of natural enemies.

Lifetime reproductive success is difficult to estimate for solitary bees but for most species is low (Danforth et al. 2019). Some species of Megachilidae have been reported to exceed 25 offspring per female (Levin 1966; Sugiura and Maeta 1989; Kim 1997) but estimates from species in other bee families rarely exceed 10-15 (Visscher and Danforth 1993; Giovanetti and Lasso 2005; Rehan and Richards 2010) and sometimes are less than five (Gebhardt and Röhr 1987; Minckley et al. 1994; Field 1996). Low lifetime fitness and the amount of investment that nest construction entails for a female solitary bee suggests that loss of brood to natural enemies must generally be low or populations of solitary bees 
would not remain viable. The data compiled in this survey is consistent with this observation. Nevertheless, this survey suggests more data are needed on bees in families other than the Megachilidae, and on species found outside the Nearctic. A useful outcome of this study is if more researchers report the number of larval cells they examine and their contents so more detailed comparative studies will be possible on population dynamics of solitary bees and their natural enemies.

\subsection{General summary}

We compiled studies from the literature that reported the contents of solitary bee brood cells to assess the cause and frequency of larval bee mortality. A taxonomically rich set of natural enemies attack solitary bees using an array of tactics to gain access to the nest. Mortality by pathogenic microbes or bacteria, developmental problems from egg to adult, or other unknown causes are not uncommon. Although a few studies report high loss of solitary bee brood to a species-rich set of natural enemies, most studies report losses of less than $20 \%$. Brood parasitic bees are the greatest source of mortality for immatures of pollen-collecting solitary bees followed by meloid beetles (Meloidae), beeflies (Bombyliidae), and clerid beetles (Cleridae). Most groups, however, are reported from only a few host species and attack a low proportion of brood cells. The suite of natural enemies that attack ground- and cavity-nesting solitary bees is very different; most reports of natural enemies that use their ovipositor to pierce the side of the nest to lay an egg are from bees that nest in cavities or trap nests. The cavity-nesting species have higher reported mortality due to unknown causes which may be related to how nests are manipulated and handled by researchers.

Sources et fréquence des pertes de couvain chez les abeilles solitaires

Parasite / prédateur / abeilles nichant dans les cavités / abeilles nichant dans le sol / méta-analyse
Ursachen und Häufigkeit von Brutverlusten bei solitären Bienen

Brutparasiten / Räuber / höhlennistende Bienen / bodennistende Bienen/ Metaanalyse

\section{REFERENCES}

Biani, N.B., Mueller, U.G., Wcislo, W.T. (2009) Cleaner mites: Sanitary mutualism in the miniature ecosystem of neotropical bee nests. Am. Nat. 173, 841-847

Clausen, C.P. (1940) Entomophagous Insects. McGrawHill Book Company, New York and London

Danforth, B.N., Minckley, R.L., Neff, J.L. (2019) The Biology of Solitary Bees: Biology, Evolution, Conservation. Princeton University Press, Princeton

Field, J. (1996) Patterns of provisioning and iteroparity in a solitary halictine bee, Lasioglossum (Evylaeus) fratellum (Perez), with notes on $L$. (E.) calceatum (Scop.) and $L$. (E.) villosulum (K.). Insect. Soc. 43, 167-182

Gebhardt, M., Röhr, G. (1987) Zur bionomie der sandbienen Andrena clarkella (Kirby), A. cineraria (L.), A. fuscipes (Kirby) und ihrer kuckucksbienen. Drosera 87, 89-114

Giovanetti, M., Lasso, E. (2005) Body size, loading capacity and rate of reproduction in the communal bee Andrena agilissima (Hymenoptera; Andrenidae). Apidologie. 36, 439-447

Goodell, K. (2003) Food availability affects Osmia pumila (Hymenoptera: Megachilidae) foraging, reproduction, and brood parasitism. Oecologia. 134, 518-27

Grissell, E.E. (2007) Torymidae (Hymenoptera: Chalcidoidea) associated with bees (Apoidea), with a list of chalcidoid bee parasitoids. Journal of Hymenoptera Research. 16, 234-265

Howell, A.D., Alarcón, R., Minckley, R.L. (2017) Effects of habitat fragmentation on the nesting dynamics of desert bees. Ann. Entomol. Soc. Am. 110, 233-243

Kim, J.-Y. (1997) Female size and fitness in the leaf-cutter bee Megachile apicalis . Ecol. Entomol. 22 , 275-282

Krombein, K.V. (1967) Trap Nesting Bees and Wasps. Smithsonian Press, Washington, D.C

Levin, M.D. (1966) Biological notes on Osmia lignaria and Osmia californica (Hymenoptera: Apoidea, Megachilidae). J. Kansas Entomol. Soc. 39, 524-535

Linsley E.G., MacSwain, J,W. (1942) The parasites, predators, and inquiline associates of Anthophora linsleyi. American Midland Naturalist 27, 402-417

Linsley, E.G. (1944) Natural sources, habitats, and reservoirs of insects associated with stored food products. Hilgardia. 16, 187-222

Linsley, E.G. (1958) The ecology of solitary bees. Hilgardia. 27, 543-599 
MacIvor, J.S., Packer, L. (2015). 'Bee hotels' as tools for native pollinator conservation: A premature verdict? PLoS One. 10, e0122126

Madras-Majewska, B., Zajdel, B., Grygo, M. (2011) Section analysis of after born mason bee (Osmia rufa L.) material. Ann. Warsaw Univ. Life Sci. 108, 103108

Minckley, R.L., Wcislo, W.T., Yanega, D., Buchmann, S.L. (1994) Behavior and phenology of a specialist bee (Dieunomia) and sunflower (Helianthus ) pollen availability. Ecology 75, 1406-1419

Parker, F.D. (1986) Nesting, associates, and mortality of Osmia sanrafaelae Parker. Journal of the Kansas Entomological Society. 59, 367-377

Rehan, S.M., Richards, M.H. (2010) Nesting biology and subsociality in Ceratina calcarata (Hymenoptera: Apidae). Can. Entomol. 142, 65-74

Rehan, S.M., Schwarz, M.P., Richards, M.H. (2011) Fitness consequences of ecological constraints and implications for the evolution of sociality in an incipiently social bee. Biol. J. Linn. Soc. 103, 57-67

Rosenheim, J.A. (1990) Density-dependent parasitism and the evolution of aggregated nesting in the solitary Hymenoptera. Ann. Entomol. Soc. Am. 83, 277-286

Roubik, D.W., Michener, C.D. (1980) The seasonal cycle and nests of Epicharis zonata, a bee whose cells are below the wet-season water table (Hymenoptera, Anthophoridae). Biotropica. 12, 56-60

Rozen Jr. J.G., Buchmann, S.L. (1990) Nesting biology and immature stages of the bees Centris caesalpiniae, C. pallida, and the cleptoparasite Ericrocis lata (Hymenoptera: Apoidea: Anthophoridae). American $\mathrm{Mu}-$ seum Novitates. $2985: 1-30$

Rust, R.W. (1980) The biology of Ptilothrix bombiformis (Hymenoptera: Anthophoridae). J. Kansas Entomol. Soc. 53, 427-436

Sakagami, S. F., Michener, C.D. 1962 The Nest Architecture of the Sweat Bees (Halictinae). Univ. Kans. Press, Lawrence

Smith, A., Harper, C., Kapheim, K., Simons, M., Kingwell, C., Wcislo, W. (2018) Effects of social organization and resource availability on brood parasitism in the facultatively social nocturnal bee Megalopta genalis . Insect. Soc., 65, 85-93
Spear, D.M., Silverman, S., Forrest, J.R.K. (2016) Asteraceae pollen provisions protect Osmia mason bees (Hymenoptera: Megachilidae) from brood parasitism. Am. Nat. 187, 797-803

Stephen, W.P., Bohart, G.E., Torchio, P.F. (1969) The Biology and External Morphology of Bees-with a Synopsis of the Genera of Northwestern America. Agricultural Experiment Station, Oregon State University, Corvallis, Oregon

Sugiura, N., Maeta, Y. (1989) Parental investment and offspring sex ratio in a solitary mason bee, Osmia cornifrons (Radoszkowski) (Hymenoptera, Megachilidae). Japanese J. Entomol. 57, 861-875

Visscher, P.K., Danforth, B.N. (1993) Biology of Calliopsis pugionis (Hymenoptera, Andrenidae) - nesting, foraging, and investment sex ratio. Ann. Entomol. Soc. Am. 86, 822-832

Wcislo, W.T. (1984) Gregarious nesting of a digger wasp as a "selfish herd" response to a parasitic fly (Hymenoptera: Sphecidae; Diptera: Sacrophagidae). Behav. Ecol. Sociobiol. 15, 157-160

Wcislo, W.T. (1987) The roles of seasonality, host synchrony, and behaviour in the evolutions and distributions of nest parasites in Hymenoptera (Insecta), with special reference to bees (Apoidea). Biol. Rev. 62 , 515-543

Wcislo, W.T. (1996) Parasitism rates in relation to nest site in bees and wasps (Hymenoptera: Apoidea). J. Insect Behav. 9, 643-656

Wcislo, W.T., Minckley, R.L., Leschen, R.A.B., Reyes, S. (1994) Rates of parasitism by natural enemies of a solitary bee, Dieunomia triangulifera (Hymenoptera, Coleoptera and Diptera) in relation to phenologies. Sociobiology. 23, 265-273

Wuellner, C.T. (1999) Nest site preference and success in a gregarious, ground-nesting bee Dieunomia triangulifera. Ecol. Entomol. 24, 471-479

Publisher's note Springer Nature remains neutral with regard to jurisdictional claims in published maps and institutional affiliations. 